\title{
Perspectives of Students Enrolled in the Program of General Diploma in Education at Najran University regarding the Accomplishment of Its Aims
}

\author{
Ameen Mohammad Nimer \\ College of Education, Najran University, Najran, KSA \\ Email:nimir_4@hotmail.com
}

How to cite this paper: Nimer, A.M. (2017) Perspectives of Students Enrolled in the Program of General Diploma in Education at Najran University regarding the Accomplishment of Its Aims. Open Journal of Social Sciences, 5, 175-194.

https://doi.org/10.4236/jss.2017.52017

Received: January 22, 2017

Accepted: February 21, 2017

Published: February 24, 2017

Copyright $\odot 2017$ by author and Scientific Research Publishing Inc. This work is licensed under the Creative Commons Attribution International License (CC BY 4.0).

http://creativecommons.org/licenses/by/4.0/

\section{(c) (i) Open Access}

\begin{abstract}
The present study aimed to identify the extent to which the program of General Diploma in Education at Najran University could accomplish its aims from the perspectives of students enrolled in the program in the current academic year and the perspectives of a sample of graduates in previous years. To do so, a two-dimension questionnaire was developed. Items in the first dimension measured the accomplishment level of participants' cognitive and cultural side while items in the second one tested the participants' skill and professional aspect. Results showed that the program's aims were achieved in a moderate extent and such result required, of course, a thorough review of the entire program, particularly strengthening the cultural aspect. Performance evaluation with regard to practicum or field training and enhancement of the skill aspect regarding scientific research and self-learning were important, too. Furthermore, negative issues that were not of a fundamental benefit for the teacher joining the program should be reduced, whereas it was very crucial to promote the program's positive aspects and practices.
\end{abstract}

\section{Keywords}

In-Service Training, Teacher Competences, General Diploma in Education, Effective Teaching, Najran University

\section{Introduction}

Technological, social, cultural, political and economic challenges and developments that globalization produced have affected the educational environment all over the world in general, and particularly the Arab world. They have been continual pressures on school to reevaluate its aims, roles and practices to harmon- 
ize requirements of current reality for the sake of developing its outcomes and be an educational environment that can graduate responsible students towards themselves and others. Graduates should be also equipped with a set of knowledge and skills that help them go on in their educational process at university or join the labor market, which looks for highly trained and qualified manpower which is capable of creation innovation and adaptation to increasing variables. Therefore, there should be a continuous renewing process of all elements within the school environment to keep pace with rapid development qualitatively and quantitatively. Success of all these things depends on the impact power resulting from the interaction and interdependence of a number of factors such as curriculum, conditions of educational environment including the concrete means and the potentials, and equipment available for the education process. The teacher, on the other hand, who is the main pillar in the educational process should be affected by this success and should create the desired change in education quality and output. Dewey, cited in [1], believes that all educational reforms are restrained by the rehabilitation of education stakeholders' quality and personality. Thus, there is a consequent importance of modern experience establishment, which is related to the educational environment and fits for the nature of change that accompanies community development [2]. Reference [3] argues that the importance of accelerating teacher development and qualification is due to a main cause, which is called economy transfer that is based on the industry of knowledge, information and creation-based economy. Therefore, there is a need for the teacher to go back to school in order to get additional learning and training that parallels the size of development taking place in knowledge, technology, administration, and various skills that contribute to his professional development [4]. That is, it is not possible to achieve success away from a competent teacher who is well prepared and trained. The knowledge structure of the teacher, his educational conduct and practices, by which experiences and cognitive and scientific activities are organized, are of the most important elements that help achieving the educational aims. The competent teacher, on the other hand can make up any probable shortage or failure in the teaching courses, available material and technical potentials [5].

Teacher preparation programs regardless perfection and precision they have will not be able to provide the teacher with solutions for all problems that meet him within the educational process and keep his teaching competency. The rapid scientific evolution in creating better teaching ways and the consequent findings of psychology need a teacher continual training program that promotes his permanent growth. In addition, diagnosis of difficulties facing scholars in the educational programs is an entrance to evaluate the effectiveness of these programs and consider their problems. The aim should not be punishment as much as a search for better alternatives in the delivery of services in more efficient ways [6].

\section{Statement of the Problem}

Universities bear the responsibility of developing and training in service teachers 
by designing integrated programs for those who wish to join the teaching profession, or those who joined it without having an educational qualification. However, it is observed that there is a shortcoming in pre and in service teacher preparation and training that leads to a traditional stereotype dominated by repetition of previous programs. The impact of these programs is rarely reflected on the educational situation and what educators and researchers have detected regarding the lack of echo of the impact of these programs on teachers in educational contexts emphasizes this hypothesis. Arab teacher is still in the traditional stereotype despite the fact that these training programs have emerged for decades in the Arab world. School outputs of students are still of the same cognitive level. In other words, there is no good movement regarding this aspect, which raises a problem like "the ability of teacher training programs to contribute to the creation of a model teacher in the $21^{\text {st }}$ century. Such programs should help enrolled students acquire the required skills and powers in a modern spirit. Hence, some important concepts related to teacher training and the requirements of teaching profession should be seriously discussed. Track and survey processes of the general diploma in education at Najran University reveals that it is consisted of two academic years and (32) credit hours among which are (4) hours for practicum. Having a look at the program's mission and aims, one can claim that mission is centered on teachers' high-level rehabilitation in accordance to educational and professional knowledge and skills that fulfill the needs and requirements of their community. In addition, the program aims were:

1) Allow university graduates of various disciplines to join teaching profession.

2) Provide students with educational and psychological knowledge, concepts and theories.

3) Train students on different skills of communication through Knowledge resources.

4) Develop leadership skills and promote self-reliance and responsibility.

5) Prepare students to use computer technology and applications in the educational process.

6) Build the character, which is capable of self-learning and continuing education.

7) Develop the skills of scientific research to meet the educational problems.

8) Train students on various teaching skills and learning styles.

9) Develop the moralities of profession.

Reconsidering the program of the general diploma in education offered by Najran University, it is seen that it provides the enrolled teacher with various developmental aspects, i.e. cognitive, cultural, skills and professional. Therefore, the present study will try to answer these questions:

1) To what extent does the program of General Diploma in education at Najran University accomplish its aims from the perspectives enrolled students?

2) Are there any statistically significant differences between participants' views regarding aims achievement of the General Diploma in Education regarding the 
state of participants whether graduates or non-graduates?

3) Are there any statistically significant differences between participants' views regarding aims achievement of the General Diploma in Education regarding participants' gender?

4) Are there any statistically significant differences between participants' views regarding aims achievement of the General Diploma in Education regarding participants' areas of specialty whether scientific or literary?

Importance of the present study is clearly seen because in-service teachers' rehabilitation and training system is witnessing tremendous and rapid change all over the world. There has been a quantum leap in technology, cognitive mutation that has connected to the educational process and its development. On the opposite, we as researchers in the Arab world should check and evaluate the content of the rehabilitation programs provided for our teachers at our universities in light of all developments that take place in reality. We have to revise the reality and credibility of these programs to meet teachers' aspirations and change their conduct, teaching methods, relations with students and quality of their outputs.

\section{Theoretical Framework and Previous Studies}

\subsection{Effective Teaching}

The evolution in the educational process through the entry of technology, the revolution in communications and information, and scientific progress all have helped the great knowledge flow, where information is now available, more accessible more important that what teachers used to deliver in the past. There has been a change in the teacher's role that was for a period centered on knowledge transfer and delivery to students. A new reality that needs the teacher to be highly and well-trained to cope with been created and imposed. The teacher's role in information choice, gathering, saving, presenting, revising and contributing to its building has been wider and more comprehensive [7]. School must transform from teaching basic skills to a school of thinking that develops higher-order thinking skills at various stages of education [8]. Besides, an international interest mainly in the developed countries has been started to guide teaching towards the authentic achievement that is based on three main objectives [9]:

1) The learner has to produce knowledge rather than retrieving or listing what he has read.

2) The teacher has to use inquiry approach to build the meaning of what the learner has learnt.

3) The learner has to look for the production of meaningful knowledge and achievements and not only to pass at school.

Effective teaching refers to that kind of teaching, which requires learners to produce rather than retrieve what they have already learnt. Their achievements should be valuable and precious for their communities [10]. Realistic teaching refers to that kind of teaching, which applies strategies of higher order thinking 
skills, clarifies issues in depth, connects lessons to learner's real life, involves teachers and learners in substantial dialogues, and uses social support to upgrade learner's achievement and makes him participate in lessons effectively [11]. "Today's school needs teacher to contribute to the formation and development of human personality. He should have potentials and skills in counseling, guidance, teaching art, relationship establishment, research and inquiry" [12]. These potentials are needed because there is a learner with specific traits, and there is a home environment from which this learner comes affected by its conditions. There is also a physical environment in the classroom and school community. There are different tools, aids and teaching materials and more important a big community that needs successful citizens whether in his private or public life. Thus, scientific literacy should be accomplished because it develops rational thinking, helps the individual to discover his surroundings where he lives, and understands daily issues. Scientific literacy, therefore is a combination of concepts, history and philosophy, which helps to understand scientific issues [13]. Information technology contributes to the achieving of educational goals. It also speeds up learning process, develops courage, nourishes the chance to take quick steps toward scientific research, and contributes to greater understanding, fluency and expression, due to several reasons, among which is the fact that the teacher does not monopolizes knowledge but disseminates among all people [14].

\subsection{Teacher Competences}

Teacher's expertise and knowledge in his subject area, linguistic abilities and verbal fluency, knowledge of teaching and learning methods, teaching experience, and his perception of the nature of society and culture and their relation to all dimensions of the educational process play significant roles in making his impact more positive and significant [15]. Consequently, the teacher's knowledge content should include seven types of knowledge. It should have knowledge of course content; general and specific pedagogy; curriculum; learners and their characteristics; educational contexts; and knowledge of aims and goals [16]. Other researchers believe that teacher needs four competences, which as soon as accomplished contribute to his ownership of competent and effective performance. These competences are mastery of theoretical information about learning and human behavior, mastery of information in his subject area, having trends that contribute to speed up the learning process and establishing and improving human relationships, and having skills related to teaching that are essential to a student learning [17]. There is also another trend, which argues that teacher rehabilitation is based on preparing him culturally, academically and educationally. Cultural preparation involves providing him with overall knowledge about the main aspects of humanistic, natural, and social activity. Academic preparation means studying the teaching materials, which he is going to teach to students. Educational preparation refers to providing him with a set of technical and educational skills that empowers him to teach effectively and competently [18]. Others believe that teacher competences are centered on his 
knowledge, performance outputs [17].

\subsection{Teacher Professional Development}

Interest in the teaching profession has increased in recent decades. Private groups, institutes, and centers have paid attention to preparing teachers academically, professionally, and culturally. They have been creating programs that provide teachers with educational knowledge and professional skills to activate their abilities and talents for the sake of performing their role appropriately [19]. Teaching is one of the professions that owners look forward to developing its performance and raise its level because man is the core of the educational process. Man, during his life span and behavior, is in a continuous and renewed movement. He develops along with time and circumstances. It is important to emphasize the fact that training should be during periods that suit the teacher physically, mentally, and emotionally to enable him acquire new knowledge and skills. Continual growth in this profession is very important in order not to have repeated and routine work without an educational spirit, otherwise the teacher will suffer from a state of intellectual stagnation that has serious effects on his performance. Professional development is known as a developmental, constructive, continuous, and participatory process targeting teachers and other workers in the field of education to change and develop their performance, practices, skills, and cognitive, educational, technical, administrative and moral competences. It aims to bring about positive changes in the behavior and attitudes of teachers and other workers in the teaching-learning process [20]. Systems of sustainable and professional teacher development need the work on a set of things like:

1) Teacher's technical development and how to employ it in the learning environment,

2) Training him on survey and inquiry,

3) Empowering him of the skills of modern constructive pedagogy,

4) Raising his awareness of globalization challenges and emerging changes,

5) Developing him for his new roles as by changing it from of mere transmission of knowledge to an educator who cares about students,

6) Developing him culturally in the field of literature, humanities, science fiction, creative activities and aesthetic sense, and

7) Providing him with the skills that enable him to absorb and understand learners' needs and educational dealing with them.

Technical and humanistic forms are of the models used to stimulate and improve professional development of teachers. Each of the two models reflects different interests, which aim to stimulate and support professional development. Both models seem to be integral rather than represent two different ways to improve the educational process.

The aim of teacher professional development is lead him to the stage of empowerment that means his ability to achieve quality in his performance regarding specific criteria. It involves external and internal dimensions. The external 
one requires the availability of qualitative elements in the in teacher's supporting structure. The second dimension represents teacher's continuing search to promote himself professionally. This promotion requires internal accountability, which refers to one's internal control and sense of responsibility [21].

\subsection{In-Service Training}

Many current trends believe that teacher preparation does not end at the organization that declares that it would train a teacher, the degree he has got to recognize his status in the future, or when he practices his role efficiently as the case in traditional school [22]. Scientific and theoretical knowledge of the course content of the academic topic is not enough to make the teacher able to teach effectively [23]. The existence of a set of teaching skills is also not sufficient to make the teacher perform well. Each field of knowledge needs specific strategies to enhance teacher's performance in front his class [16]. The teacher's performance declines and gets weaker when he teaches a new course or material. $\mathrm{He}$ has, therefore to receive additional training that helps him to teach it appropriately [24]. Getting more continuous development and training in in-service rehabilitation programs is very important, as indicated in [25], because of a set of reasons such as:

- Rapid development of human knowledge.

- The emergence of new trends in the field of education.

- The speed of social, political, and economic changes that made it important for the teacher to recognize the quality of these variables and their effect on the learner.

- The development of education technology.

- The opportunity for professional growth and career promotion.

In-service training is also an opportunity to guarantee continuous improvement and progress for the teacher. It decreases the disadvantages of backwardness resulting from the weakness in preparation. In-service training can be of various forms. It can be integrative because of the shortcomings resulting from teacher preparation at his institute. It can be remedial to treat some weakness in one of teacher's competences. It can be renewal to go along with scientific and educational developments. It can be training for business and new tasks when a teacher in nominated for another educational task outside the classroom. In addition, in-service training can be resuscitative, which is provided for in-service teacher to revitalize him with more knowledge and skills, as well as to develop his positive attitudes towards the educational work [26]. Part of in-service growth is the responsibility of the teacher. He should be knowledgeable and familiar with all scientific theories, upon which his practice depends. He should be aware of change in these theories, and thus what change it requires in practice [27]. This, of course, pushes him to be able to read and understand scientific researches, connect them to his practice, and take advantage from them in his educational applications in his field of specialty [28]. In-service training, as in [29], is an opportunity for teachers to enhance their disciplinary education by 
accessing the latest in their area of specialization. The capital of most teachers, when joining teaching profession, is only their humble preparation. Saleh, cited in [30], points out those teachers' preparation and habilitation are better than experience. Instructing teaching skills as concepts and bases affect teacher's good performance whether experience interfered or not. The use of modern instead of traditional methodology that depends on lecturing have led to the acquisition of and understanding much of knowledge in a short period. In-service training is used for the compensation of inappropriate or weak teaching skills when teachers join the profession. Such skills are because of a shortage in their pre-service preparation or their lack of such skills as they start practicing as soon as they get academic qualifications but not disciplinary ones. Inappropriate skills might appear because of the insertion or use of educational developments in the teaching process. In-service training is referred to as an organized trial to create the desired change. It is the change in practices, attitudes, and beliefs inside the educational environment. It also involves changes in students' outcomes [31]. In teacher in-service preparation and development programs, there is a set of elements that should be accounted for, like: providing teachers with information and theories about new teaching methods and let teachers during preparation practice them. Teachers should be allowed the opportunity to experience and evaluate these new methods during training via preparing a series of presentation models of the courses they teach. In-service teacher professional development should include higher order thinking skills and activities [32]. Quality of in-service teacher training program can be measured by its ability to raise or promote their skills in using effective teaching methods to teach thinking [33]. The main aim of in-service teacher training and preparation is to empower him to realize the reality of the teaching process with all its fundamental and important inputs. Knowledge should be changed into technical and educational skills used by the teacher in the teaching situations that faces him inside classrooms while practicing teaching profession [18]. In light of the continuing need for developing educational programs in general, and teacher preparation one particularly, there is a need to develop the programs of higher diploma in education to develop in-service teachers. Development process needs asking a set of questions related to the aims, outcomes, learners' characteristics, and program's weakness and strength [34]. Intuitions of teacher preparation in America have stated a set of criteria that should be available in these programs. These criteria involve, for instance [35],

1) The importance for the preparation institutions to have a comprehensive view that proves the clarity of teacher's vision,

2) There should be a set of evaluation procedures,

3) Implementing party should have all resources and physical and humanistic potentials,

4) Preparation institution should announce its criterion for learners' graduation,

5) Preparation institution should be accredited by an outside independent in- 
stitution,

6) Preparation institution should have qualified staff or faculty to teach all specialties,

7) Preparation institution should have a program for scientific research and means for its support and encouragement, and more importantly,

8) Certainty that makes it confirms that graduates will have a high level of performance.

Joyce \& Showers [33] concluded that short term and intermittent does not fulfill the required aim to reach teacher's professional development. Teachers can not be forced to change, but they can be given the chance to understand it and be convinced of its usefulness and applicability at schools. All this can be achieved by working with and helping them during training. It is well known that students who have been taught by highly qualified teachers always have better academic achievement in all learning stages than colleagues who were taught by low qualified teachers. Teacher's impact on learners exceeds the impact of other factors such as textbook, class size, and equipment [36].

\section{Previous Studies}

Results of [4] indicated that Professional Diploma in Education at University of Jordan, to a moderate extent, achieved its aim and fulfilled the needs of the targeted group in developing their cognitive, skills, and and attitudes towards the teaching profession. Students' levels of satisfaction with faculty members' performance, used teaching methods, and physical environment were moderate, too. Results of [34] and [37] revealed a set of causes, as viewed by students, which hindered the program from achieving its aim. Theses causes include poor performance in practicum, lack of training environment readiness for training and poor performance of faculty members and scientific material presented to students. Reference [38] showed that the most important obstacles that hinder the achievement of diploma in education program were centered on the poor practicum, i.e. lack of guidance provided to students by their academic supervisors and number of visits at schools of training. Differences between specialties of academic supervisors and students hindered the provision of appropriate guidance. Reference [39] concluded that in-service teacher training helped them establish positive attitudes towards the use of technology in education. Therefore, the study recommended in-service training to design applications for electronic games software that might be used in teaching courses activities. Reference [40] stated that general diploma at the college of education at Sultan Qaboos University achieved its hoped aims to a large degree. There was integration between the program aims and the aims of most courses. Courses' studying was effective in the student teacher's professional development and acquisition of scientific thinking skills. Reference [41], on the other hand, pointed out that there was no problem reading the students' cognitive preparation while studying the general diploma in education at King Abdul Aziz University. The prominent barrier for achieving the program's effectiveness referred to its short time in 
comparison with time devoted to theoretical aspects. Lack of learning resources, computers, and laboratories that creates fertile environment for professional training at schools was another important barrier. In addition, reference [42] revealed that scientific literacy level among students enrolled at education diploma program at Jordanian universities was fair. There were significant differences between participants' views due to scientific majors and years of experience in favor of less than ten years of experience. No significant differences were found due to gender. Intensification of courses that have cultural and scientific character during their academic study at university was the most important recommendation. Reference [43] indicated that programs of in-service teacher preparation and habilitation at public Jordanian universities improved the various practices of teachers in various aspects. Those aspects included academic aspect, i.e. cognitive and cultural, lesson plan design, teaching methods, and communication and relationships with others. Improvement in these aspects gradually led to their sense of professional development. Reference [44] showed that classroom activities, professional development in higher order thinking skills, and training insides the laboratory that in-service teachers received was positively reflected to learners' achievement by (40\%) more than before. It led to the improvement in teacher's practices inside the classroom. The study, at the end recommended a long term training to gain the expected benefit. Reference [45] showed that achievement level of the aims of in-service teacher habilitation program at Mutah University in Jordan was moderate in the tested areas like, program objectives, scientific content, teaching methods, evaluation methods, and facilities available in the program. No significant difference were found due to gender and specialization. Reference [18] mentioned that aims of the aims of the program of higher diploma in education were highly accomplished in aspect like, involved information and skills, teaching methods, evaluation, student counseling and guidance, relation between school and community, educational administration, humanistic relations, teaching aids, teacher's mission, and attitudes towards teaching profession. Reference [46], through a comparison between the School of Professional Development and traditional teacher preparation program in Pennsylvania, found out that although the two programs were important, the program of School of Professional Development was superior. It was more specialized and skill in the provision of good practical experience than the traditional program. The study stressed the importance that such program has to be accompanied by strength in the academic specialty and scientific material to be taught.

\section{Methodology}

\subsection{Study Design and Instrument}

The study used the descriptive analytical approach to achieve the aims. A two-part questionnaire was developed for this sake. The first part included general information about the participants such as gender, specialty, nature of respondent whether a current student or a graduate. The second part consisted of 
two main aspects. The first one was referred to as cognitive and cultural aspect and involved (12) items, whereas the second one expressed the skill and professional aspect and consisted of (14) items.

\subsection{Instrument Validity}

To make sure of the questionnaire's validity, it was presented to a set of arbitrators who were faculty members at the college of education. After revising their comments and views by modifying some items, the final version was developed and involved (26) items.

\subsection{Instrument Reliability}

To check the questionnaire's reliability, Cronbach-Alpha was used. It was applied to an exploratory sample of (15) students who were registered at the program. Two weeks later, application was repeated. Correlation coefficient was calculated and was (0.90) as shown in Table 1.

\subsection{Data Analysis}

Data were analyzed using the statistical program (SPSS). Means, standard deviations, T. test, and Cronbach-alpha were used to extract the findings and then analyze and explain them by reference to the theoretical framework and previous studies.

\subsection{Participants}

The study involved all students enrolled in the program of General Diploma in Education in the academic year 2016-2016. They were (25) males and (25) females. Their total number was (50). In addition, the study surveyed the views of (18) teachers who graduated in the academic year 2013-2014.

\subsection{Participants' Response Method}

To judge the mean scores of questionnaire items and aspects, Likert Trio Scale was used to classify the participant's response degree as shown in Table 2.

Table 1. Reliability coefficients for the items in each aspect and the questionnaire as a whole.

\begin{tabular}{lccc}
\hline N. & Aspect & Reliability Coefficient & Items No. \\
\hline 1$)$ & Cognitive and cultural & 0.82 & 12 \\
$2)$ & Skill and professional development & 0.86 & 14 \\
$3)$ & The questionnaire as a whole & 0.90 & 26 \\
\hline
\end{tabular}

Table 2. Classification criteria for response degree importance.

\begin{tabular}{ccc}
\hline Number & Mean & Degree \\
\hline 1$)$ & $2.34-3.00$ & High \\
$2)$ & $1.67-2.33$ & Moderate \\
$3)$ & $1.00-1.66$ & Poor \\
\hline
\end{tabular}




\section{Findings and Discussion}

\subsection{Findings Related to the First Question}

To answer the first question "To what extent does the program of General Diploma in education at Najran University accomplish its aims from the perspectives enrolled students?" mean scores, standard deviations for each aspect were calculated. Mean score and standard deviation for the two aspects as a whole were also extracted. Table 3 shows the results.

Table 3 indicates that the mean score of participants' responses to the statements in the cognitive and cultural aspect was moderate $(M=2.28)$. The result revealed that the least response degree $(M=1.53)$ was attached to statement number (11) that showed the acquisition level of the teachers enrolled in the program regarding their knowledge of the impact of social, economic, political, management relations on the whole teaching process. That is, participants felt that they were not exposed to all aspects that affect the teaching process. On the opposite, the highest response degree $(\mathrm{M}=2.74)$ was related to statement number (4) that revealed the acquisition level of the participants in accordance to the terms, concepts, and new vocabulary in the educational affairs through program courses. In other words, the program was effective in the provision of good cognitive repository to students in its theoretical framework. This finding is consistent with other studies like, [4] [41] [42] [43] and [45] regarding the fact that the cognitive aspect in the program of General Diploma in Education usually

Table 3. Mean scores and standard deviations for cognitive and cultural aspect.

Items

1) General Diploma in Education increased my cognitive knowledge of theories and philosophies that orient the educational system.

2) During the program, I had a look at international distinguished experience and models in the educational field.

3) The program empowered me to identify modern technological developments and the areas of their use.

4) I identified the terms, concepts, and new vocabulary in the educational affairs through program courses.

5) My study in the program raised my motivation towards deepening my specialization and enriching the teaching material I present to my students.

6) My study in the program raised my knowledge of the importance of teaching profession, its morals, and supreme mission.

7) Studying in the program was useful for me because it helped me understand the integrative roles of teacher in the teaching environment.

8) Feedback and continuous evaluation for my performance in practicum provided me with cognitive, cultural, and skill experience.

9) My study in the program developed my awareness of the problems and new developments of local and international communities.

10) My study in the program provided me with a clear vision about teaching and its aims, objectives, and mission.

11) I could realize the impact of social, economic, political, management relations on the teaching process.

12) My study of some courses in the program enhanced and promoted my understanding of humanistic nature and the determinants of its behavior.

\section{Rank M. S. D. Agreement degree}

$3 \quad 2.690 .526 \quad$ High

$9 \quad 1.960 .908 \quad$ Moderate

$8 \quad 2.240 .690 \quad$ Moderate

$1 \quad 2.740 .582 \quad$ Moderate

$7 \quad 2.33 \quad 0.793 \quad$ Moderate

$4 \quad 2.67 \quad 0.631 \quad$ High

$2 \quad 2.700 .622 \quad$ High

$10 \quad 1.840 .911 \quad$ Moderate

$11 \quad 1.710 .764 \quad$ Moderate

$5 \quad 2.640 .674 \quad$ High

$121.530 .756 \quad$ Poor

$6 \quad 2.44 \quad 0.715 \quad$ High 
offers a qualitative and special addition about the education affairs. However, the program was less effective in accordance to the cultural aspect. Results showed that practicum was effective and did not reach the desired level as expressed by participants' responses. Responses to the statement "Feedback and continuous evaluation for my performance in practicum provided me with cognitive, cultural, and skill experience" $(M=1.84)$ showed that participants were not satisfied with the program's ability to provide them with something new or fundamental during the practicum course. This finding corroborates the findings of [34] [37] and [38] that showed that ineffective practices during practicum influenced the program's outcomes achievement level.

Table 4 presents the mean scores and standard deviations for the skill and professional aspect.

Table 4 indicates that the mean score of participants' responses to the statements in the skill and professional aspect was moderate $(M=2.19)$. The result revealed that the least response degree $(M=1.50)$ was attached to statement number (6) that showed the acquisition level of the teachers enrolled in the program regarding enhancement of their scientific research skill and ways of its activation in classroom. That is, participants felt that the diploma program could not promote such a skill regardless its importance to transfer teachers from the traditional side in teaching towards the side, which is more effective and participatory

Table 4. Mean scores and standard deviations for the skill and professional aspect.

\begin{tabular}{|c|c|c|c|}
\hline Items & Rank & M. S.D. & reement degree \\
\hline $\begin{array}{l}\text { 1) I feel that my skills in school management and class control have developed after joining the General } \\
\text { Diploma in Education. }\end{array}$ & 8 & 2.200 .754 & Moderate \\
\hline 2) My study in the program empowered me to use technology and its applications in teaching environment. & 11 & 2.030 .798 & Moderate \\
\hline 3) My study in the program empowered me to vary my teaching methods inside classroom. & 6 & 2.230 .765 & Moderate \\
\hline $\begin{array}{l}\text { 4) My study in the program promoted my ability to cope with educational problems, in general and } \\
\text { particularly, classroom ones. }\end{array}$ & 9 & 2.130 .815 & Moderate \\
\hline 5) Study in the program encouraged me to develop the scientific curriculum and contribute to enriching it. & 5 & 2.290 .725 & Moderate \\
\hline 6) My enrollment in the program fostered my scientific research skill and ways of its activation in classroom. & 14 & 1.500 .717 & Poor \\
\hline $\begin{array}{l}\text { 7) My study increased my interest in looking for innovation aspects among students and trying to develop } \\
\text { them. }\end{array}$ & 12 & 1.940 .883 & Moderate \\
\hline $\begin{array}{l}\text { 8) My communication and relationships with profession partners like teachers, students, and managers } \\
\text { improved after joining the program. }\end{array}$ & 3 & 2.750 .753 & High \\
\hline $\begin{array}{l}\text { 9) My interest in taking into account spiritual, psychological, physical and moral aspects increased after } \\
\text { joining the program. }\end{array}$ & 7 & 2.210 .815 & Moderate \\
\hline 10) My study in the program helped me to refine the skill of self-learning and cognitive structure of all types. & 13 & 1.830 .761 & Moderate \\
\hline $\begin{array}{l}\text { 11) My ways of evaluating students inside classroom varied according to the different activities that were } \\
\text { assigned to me. }\end{array}$ & 4 & 2.470 .653 & High \\
\hline 12) Joining the program fostered my self-confidence in front of colleagues and students. & 1 & 2.630 .663 & High \\
\hline $\begin{array}{l}\text { 13) My study in the program diminished my negative attitudes towards teaching profession and developed } \\
\text { the positive ones towards teaching profession. }\end{array}$ & 10 & 2.060 .700 & Moderate \\
\hline $\begin{array}{l}\text { 14) My enrollment in the program in the program increased my sense of responsibility towards teaching } \\
\text { profession and its supreme mission. }\end{array}$ & 2 & 2.590 .732 & High \\
\hline \multicolumn{2}{|l|}{ General mean } & 2.190 .196 & Moderate \\
\hline
\end{tabular}


in classroom. At the other end of the scale, the highest response degree $(\mathrm{M}=$ 2.63) was related to statement number (12) that revealed participants' perceptions were high in accordance to the program's ability to foster their self-confidence in front of colleagues and students. That is, participants were satisfied with the increase in the level of confidence they could get from the diploma program. This finding asserts the findings of other studies like, for instance, [4] and [43] according to the relationships and communication with others within profession framework. Nevertheless, it disagrees with findings of [18] with regard to the program's ability to help students establish positive attitudes towards teaching profession, school management, and teaching methods.

Table 5 shows the mean scores and standard deviations for the questionnaire as a whole.

Table 5 reveals that the extent to which the General Diploma in education at Najran University has achieved it aims was moderate. Achievement mean score of all items in the study instrument, which was the aim of the first question of the present study, was (2.23) and the standard deviation was (0.168). This finding indicates that The General Diploma in Education at Najran University has satisfactorily achieved its objectives although it has not satisfied the ambitions of enrolled students. Reasons for this can be referred to the fact that the program is still working traditionally and has not modified its practices and procedures to form a fundamental difference when a teacher is enrolled in it. Besides, teachers have not acquired qualitative addition that has been reflected to his practices inside the classroom. Practical training or practicum did not also provide enrolled teachers with a qualitative experience inside classroom but it was limited to advice and guidance. No fertile physical environment was available for conducting practicum appropriately.

\subsection{Findings Related to the Second Question}

To answer the second question "Are there any statistically significant differences between participants' views regarding aims achievement of the General Diploma in Education regarding the state of participants whether graduates or non-graduates?", mean scores, standard deviations and T. Test for the significance of differences between the mean scores of participants' responses regarding the achievement of the program's aims were calculated. Results are shown in Table 6.

Table 6 indicates that there are significant differences between both kinds of participants whether students in the program or graduates in favor of program's graduates in earlier years. That is, program's graduates mean scores regarding the program's aims achievement in the cognitive and cultural aspects were higher

Table 5. Means and standard deviations for the questionnaire as a whole.

\begin{tabular}{cccc}
\hline Aspect & Means & Standard deviations & Accomplishment degree \\
\hline Cognitive and cultural & 2.28 & 0.234 & Moderate \\
Skill and professional & 2.19 & 0.196 & Moderate \\
The whole questionnaire & $\mathbf{2 . 2 3}$ & $\mathbf{0 . 1 6 8}$ & moderate \\
\hline
\end{tabular}


than the scores of students who were still enrolled in the program. These findings could be due to the irregular study in the academic year when the perceptions of students enrolled in the program were tested where attendance was not counted. Thus, there was a lack of students' attendance and consequently a lack of gaining theoretical knowledge. Attendance in earlier years was obligatory and counted and so graduates had the opportunity to acquire grater theoretical knowledge.

\subsection{Findings Related to the Third Question}

To answer the third question "Are there any statistically significant differences between participants' views regarding aims achievement of the General Diploma in Education regarding participants' gender?", mean scores, standard deviations and $T$. Test for the significance of differences between the mean scores of participants' responses regarding the achievement of the program's aims were calculated. Results are shown in Table 7.

Table 7 shows that there were statistically significant differences between participants' responses to skill and professional aspect in favor of females. Such a result indicates females' interest in skills and professional aspect was higher than the interest of males. One possible cause for this might be the difference between faculty members, because co-education at university is not allowed. Male faculty members taught male students and female faculty members taught female ones. In addition, the fact that female faculty members have greater keenness to provide their students with a set of more in-depth and specialized teaching skills than males might be another cause.

Table 6. Mean scores, standard deviations and T. Test for the significance of differences between the mean scores due to learners' variable (graduate/non-graduate).

\begin{tabular}{|c|c|c|c|c|c|c|}
\hline Aspect & Participant state & e M. S.D. ? & $\mathrm{T}$. value & D.F. & Sig. (2-tailed) & Mean Difference \\
\hline \multirow{2}{*}{ Cognitive \& cultural } & Student & 2.240 .224 & \multirow{2}{*}{-2.301} & \multirow[b]{2}{*}{68} & \multirow{2}{*}{0.024} & \multirow[b]{2}{*}{-0.138} \\
\hline & Graduate & 2.380 .236 & & & & \\
\hline \multirow{2}{*}{ Skill \& professional } & Student & 2.220 .201 & \multirow{2}{*}{1.810} & \multirow{2}{*}{68} & \multirow{2}{*}{0.075} & \multirow{2}{*}{0.092} \\
\hline & Graduate & 2.130 .169 & & & & \\
\hline \multirow[b]{2}{*}{ The whole questionnaire } & Student & 2.230 .176 & \multirow{2}{*}{-0.318} & \multirow[b]{2}{*}{68} & \multirow[b]{2}{*}{0.751} & \multirow[b]{2}{*}{-0.014} \\
\hline & Graduate & 2.240 .148 & & & & \\
\hline
\end{tabular}

Table 7. Mean scores, standard deviations and T. Test for the significance of differences between participants' responses according to gender.

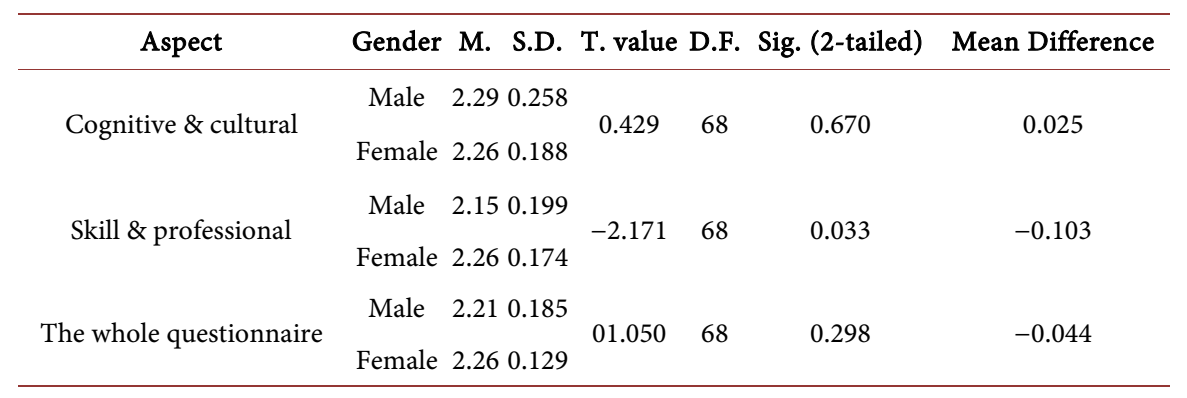




\subsection{Findings Related to the Fourth Question}

To answer the fourth question "Are there any statistically significant differences between participants' views regarding aims achievement of the General Diploma in Education regarding participants' area of specialty whether scientific or literary?", mean scores, standard deviations and $\mathrm{T}$. Test for the significance of differences between the mean scores of participants' responses regarding the achievement of the program's aims were calculated. Results are presented in Table 8.

Table 8 shows that there were no statistically significant differences due to participants' area of specialty whether scientific or literary in their evaluation of the accomplishment degree of the program's aims in both aspects. A finding like this proves that the environments where the two kinds of participants were taught were similar. In addition, their teaching practices had similar or same characters.

\section{Conclusions}

Education system at any learning environment requires a set of reform procedures and practices in all aspects. The teacher is one of these most important aspects that should be affected by reform and change due to the nature of the change that the world is witnessing in the cultural, social and economic aspects. He should be subjected to pre and in-service teacher rehabilitation and training programs. The present study has focused on in-service teacher training and rehabilitation programs and tried to test their positive impact and the extent to which they have accomplished their aims. The program of General Diploma in Education at Najran University is one of these programs that seek to achieve various aims. Measuring the extent to which the aims of this program were achieved was the main aim of the present study. Therefore, a questionnaire of two main aspects was developed to explore and survey the aspects that the program was assumed to develop or enhance, namely cognitive, cultural, skills, and professional. The first aspect involved the measurement of the cognitive and cultural aspect that students were supposed to have developed during the program. The second aspect aimed to check the learners' skills and professional aspect that they were assumed to have gained. Findings revealed that the program

Table 8. Mean scores, standard deviations and T. Test for the significance of differences between participants' responses according to area of specialty (scientific/literary).

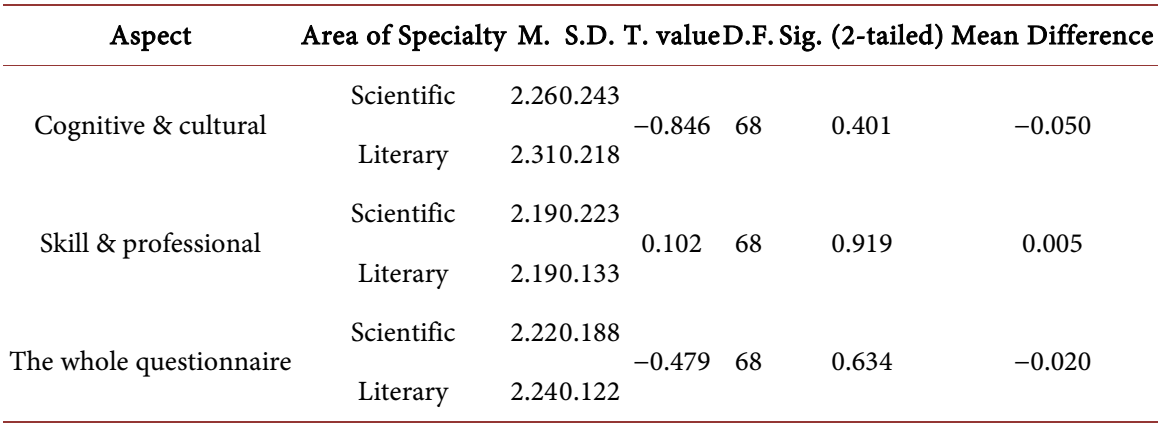


moderately achieved its aims but could not achieve learners' ambitions and aspirations to a great extent. Deficiency in the program might be because of the traditional way it was used to help learners acquire the specialized knowledge in the educational affairs or field. It did not empower learners to overcome the challenges thee face at the teaching environment nowadays. However, the program has achieved its aim through the first aspect by the provision of a group of new educational terms and concepts, the increase in learners' cognitive knowledge about theories and philosophies orienting the educational system, and learners' empowerment to understand and identify their integrative roles at teaching environment. The program also could increase the learners' awareness of the morals of teaching profession and understanding the learner's human nature, its determinants, conduct, and ways of how to deal with it. Teachers, on the other side, felt that the program did not provide them with any enrichment materials that could increase their awareness of the social, economic, and political developments or how they affect the teaching environment. Teachers did not also feel that the program helped them to identify and realize the needs and requirements of local and international communities or to predict their problems that could be reflected to the educational context. Teachers also felt that there was no positive effect of their field training as no significant or noticeable difference was made. Practicum, as stressed by teachers, was concentrated on a group of traditional practices that did not provide them with any new experience. Findings also show that interest in the technological aspect was not as well as expected or hoped. Such an interest should go side by side with rapid technological changes and developments in the present time.

With regard to the second aspect that was connected to teachers' development in skills and professional area, the program could achieve its aim to a large extent in areas like, teachers' sense that the program increased their self-confidence within the teaching environment and in front of colleagues and students. The program also raised their sense of responsibility towards the teaching profession. Teachers' ways of communication with their profession partners such as school managers, teachers, and students were highly developed. Their methods of students' evaluation were modified. Furthermore, enrollment in the program encouraged teachers to develop the curriculum provided to students and to enrich it. Their teaching methods were somehow improved, too. Nevertheless, teachers' skills in scientific research were not polished or refined because the program did not focus on doing so. Self-learning skills and cognitive structure were not acquired and consequently teachers will not be able to transfer them to their learners. One shortage in the program was its inability to help teachers explore creative aspects of enrolled students. It did not help teachers to use effectively technology in classroom. Analysis of collected data prove that enrollment in the diploma program offered by Najran University was not successful in eliminating negative attitudes towards teaching profession. It could not enhance teachers' abilities to cope with various educational and classroom problems.

In light of these findings, the present study recommended stakeholders to 
reevaluate the program and conduct overall revision for all discussed aspects and issues. They are called to correct the program's track to make an intrinsic difference among its enrolled students and to develop their cognitive, cultural, skills, and professional aspects as well as needed.

\section{Acknowledgements}

The researcher is greatly indebted to the Deanship of Scientific Research at Najran University for funding this study that holds number NU/SHED/14/174.

\section{References}

[1] Hajjaj, A. and Sheikh, S. (1982) Evaluative Study of Teacher Preparation in the Preparatory and Secondary Stages at Qatar. Educational Research Center at Qatar University, Qatar.

[2] Croll, P. and Moses, D. (1990) The Involvement of Teachers in Initial Teacher Education: A Study of the Simon Fraser University Professional Development Program. Research Papers in Education, 5, 73-92.

[3] Al-Zaydi, A. (2012) A Proposed Perception for Public Education Teacher in the 21st Century in Light of Globalization Challenges, Economic and Cultural Competition. Journal of Reading and Knowledge, 123, 179-192.

[4] Al-Daajeh, H., Al-Saaydeh, M., Al-Dojan, M. and Al-Shar'e, I. (2011) Evaluation of Professional Diploma in Education at University of Jordan. Studies, Educational Sciences, 38, 2157-2173.

[5] Al-Ajmi, L. (2013) Evaluating the Outcomes of General Preparation Program of Educational Diploma Students-Science Section-At Female Education Colleges at King Khaled University in Light of Conceptual Structure for Natural Sciences. Education, 152, 117-141.

[6] Scholossberd, N.K. (1989) Improving Higher Education Environment for Adults. Jossey-Bass Publishers, San Francisco.

[7] Demirci, A. (2009) How Do Teachers Approach New Technologies: Geography Teachers' Attitudes Geography Information Systems (GIS). European Journal of Education Studies, 1, 43-53.

[8] Bruer, J.T. (1993) Schools for Thought. The MIT University Press, Cambridge.

[9] Bakkar, N. (2000) Practice of Student Teachers for the Criteria of Authentic Teaching at College of Education at King Saud University. Massage of Arab Gulf, 21, 95 153.

[10] Duis, M. (1995) Making Time for Authentic Teaching and Learning: Gateways to Experience. ERIC Document Reproduction Service No. ED390 806, Kappa Delta Pi Record, 30, 136-138. http://eric.ed.gov/?id=ED390806 https://doi.org/10.1080/00228958.1995.10531924

[11] D'Agostino, J.V. (1996) Authentic Instruction and Academic Achievement in Compensatory Education Classrooms. Studies in Educational Evaluation, 22, 139-155. http://eric.ed.gov/?id=EJ531698 https://doi.org/10.1016/0191-491x(96)00008-9

[12] Shukri, A. (1981) Teacher and His Preparation Requirements in Contemporary Life. Journal of the College of Education, King Abdul Aziz University, 38.

[13] Hazen, R. (2002) Why Should You Be Scientifically Literate? http://www.actionbioscience.org/education/hazen.html 
[14] Sansanwal, D.N. (2009) Use of ICT in Teaching Learning and Education. Central Institute of Educational Technology, NCERT, New Delhi.

[15] Darling, L. and Bransford, J. (2005) Preparing Teachers for a Changing World What Teachers Should Learn and Be Able to Do. Jossey-Bass, San Francisco.

[16] Shulman, L. (1986) Those Who Understand: Knowledge Growth in Teaching. Educational Researcher, 15, 4-14. https://doi.org/10.3102/0013189X015002004

[17] Al-Enzi, B. (2007) Developing Teacher Competences in Public Education, Saudi Society for Educational and Psychological Sciences, Quality of Public Education, the Fourteenth Meeting, College of Education, King Saud University, Riyadh.

[18] Al-Zahrani, A. and Al-Kisnawi, M. (1993) An Evaluation Study of the Impact of Educational Preparation on Teachers Enrolled in the General Diploma in Education at Course Training Center at the College of Education at Umm Al-Qura University in Makkah. The 2nd Conference for Public Teacher Preparation in Saudi Arabia, 175-242.

[19] Al-Tartouri, M.A. and Al-Qodhah, M.F. (2006) New Teacher: Teacher's Guide in Effective Classroom Management, Amman: Al-Hamed House for Publishing and Distribution.

[20] Ammar, H. (2013) Teacher Professional Development in Light of E-Learning Strategies. http://www.edutrapedia.illaf.net/arabic/show_article.thtml?id=883

[21] Hamdan, M. (2010) Teacher Professional Development and Training for Knowledge Society. Conference of Arab education Future Reform for Knowledge Society: Experiences, Standards and Visions. Arab Center for Education and Development, Beirut.

[22] Kaplan, L. and Edelfelt, R. (1996) Teachers for the New Millennium. Corwin Press, Newbury Park.

[23] Al-Wahr, M.T. (2004) The Impact of Teacher Educational rehabilitation in the Development of Teaching Thinking for Science Teachers in Zarqa Governorate. Journal of Educational and Psychological Sciences, 5, 32-70.

[24] Tobin, K., Tippins, D. and Gallard, J. (1994) Research on Instructional Strategies for Teaching Science. In: Gable, D., Ed., Handbook of Research on Science Teaching and Learning, Macmillan Publishing Company, New York.

[25] Saafan, M. and Mahmoud, S. (2002) Teacher Preparation, Status and Roles in Public Education, Special Education and Psychological Counseling. House of Modern Book, Cairo.

[26] Al-Ahmed, N. (2005) The Effect of Intensive Training of Science Teachers Enrolled in Diploma in Education Program on the Development of Their Higher Order Thinking Skills in Planning for Teaching at Intermediate Stage. Message of Education and Psychology, 25, 27-76.

[27] Featherstone, J. (1971) Schools Where Children Learn. Lireright, New York.

[28] Al-Nojaihi, M. (1981) In Educational Thought. 2nd Edition, Arab Renaissance House, Beirut.

[29] Shahla, G. (1976) Brief in the History of Education. 3rd Edition, Ras Beirut Bookshop, Beirut.

[30] Yarkindi, A.H. (1997) The Impact of Teaching Educational Assessment Course in the Development of some Concepts, Principles and Skills among Students of General Diploma in Education at the Girls College of Education Makkah. Message of Arabian Gulf, 18, 99-154.

[31] Gusky, T. (1986) Staff Development and the Process of Teacher. Change. Educational Researcher, 15, 5-12. http://www.jstor.org/stable/1174780 
[32] Freedman, R.L.H. (1998) Constructivist Assessment. Practices ERIC Document Reproduction Service, No. ED415-118.

[33] Joyce, B. and Showers, B. (1988). Student Achievement through Staff Development. Longman, New York.

[34] Hasan, A. and Nabhani, H. (2002) Difficulties Faced by Students in the General Diploma Program At College of Education, Sultan Qaboos University and its Relationship to Academic Achievement. Journal of Educational and Psychological Sciences, 3, 54-87.

[35] Michael, D.A. and Richard, L.S. (1993) Outcome Centered Accreditation: It's Teacher Education on Ready. Journal of Teacher Education, 44, 8-181.

[36] Dyab, M. and Abd Al-Shafi, D. (2008) Egyptian Teacher Sequential Preparation in Light of International Experience and Field Results. Future of Arab Education, 14, 45-184.

[37] Al-Ghamdi, A. (2011) Difficulties Facing Students in General Diploma in Education at Taibah University and Its Relationship to Qualification Rating and Job from Teachers' Views. Studies, Educational Sciences, 38, 390-408.

[38] Al-Sabhi, A. (2002) Student Handbook in Practical Education. Scientific Publishing Center, King Abdul Aziz University, Jeddah.

[39] Awan, R.N. (2011) What Happens to Teachers' ICT Attitudes and Classroom ICT Use When Teachers are Made to Play Computer Games. International Journal of Information and Education Technology, 1, 354-359. http://www.ijiet.org/papers/57-R023.pdf

[40] Shaker, M., et al. (2006) Evaluation of General Diploma Program at the College of Education at Sultan University. Journal of Educational Sciences, 3.

[41] Tayyeb, A. (2009) Effectiveness of Students Educational Preparation in Education Diploma Program at King Abdul Aziz University. Evaluation Study, Future of Arab Education, 16, 311-348.

[42] Al-Zoubi, T., Al-Shar'a, I. and Al-Salamat, M. (2011) Level of Scientific Literacy among Teachers Enrolled in Education Diploma Program at Jordanian Universities Studies. Educational Studies, 38, 258-270.

[43] Hasan, M. (2001) In-Service Teacher Training and Rehabilitation. Vol. 88, National Center for Human Resources Development, Amman.

[44] Wenglinsky, H. (2000) How Teaching Matters: Bringing the Classroom Back into Discussions of Teacher Quality. ETS Policy Information Center Report. https://www.ets.org/research/policy_research_reports/publications/report/2000/idx n

[45] Al-Mahasneh, R. (2000) Evaluation of In-Service Teacher Training Program (General Diploma in Education) at Mutah University from the Viewpoint of Graduates. Unpublished MA Thesis, Mutah University, Mu'tah.

[46] Kuchinski, C. (2004) Beginning Educator Outcomes and Perceptions on Professional Preparation: A Comparison of Professional Development School and Traditional Education Preparation Programs. Unpublished Doctoral Dissertation, Marywood University, Scranton. 
Submit or recommend next manuscript to SCIRP and we will provide best service for you:

Accepting pre-submission inquiries through Email, Facebook, LinkedIn, Twitter, etc. A wide selection of journals (inclusive of 9 subjects, more than 200 journals)

Providing 24-hour high-quality service

User-friendly online submission system

Fair and swift peer-review system

Efficient typesetting and proofreading procedure

Display of the result of downloads and visits, as well as the number of cited articles Maximum dissemination of your research work

Submit your manuscript at: http://papersubmission.scirp.org/

Or contact jss@scirp.org 